\title{
A MÁSODIK OTTHONOK KIALAKÍTÁSÁNAK OKAI, FÁZISAI, HELYSZÍNEI AZ IPARI FORRADALOM KORÁTÓL NAPJAINKIG
}

\section{REASONS, PHASES AND LOCATIONS OF THE ESTABLISHING OF SECOND HOMES FROM THE AGE OF THE INDUSTRIAL REVOLUTION TO THE PRESENT DAY}

Csordás László ${ }^{1 *}$

${ }^{1}$ Közgazdaságtan és Jog Tanszék, Gazdaságtudományi Kar, Neumann János Egyetem, Magyarország https://doi.org/10.47833/2020.2.ECO.006

\section{Kulcsszavak:}

turizmus

második otthonok

szabadidö-lakások építése

közlekedés

\section{Keywords:}

tourism

second homes

building of leisure-time homes

transport

\section{Cikktörténet:}

Beérkezett 2019. szept. 21.

Átdolgozva 2019. okt. 31.

Elfogadva 2019. nov. 20

\section{Összefoglalás}

E tanulmány célja, hogy bemutassa a második otthon, szabadidő-lakás jelenség tömegméretüvé válásának, térbeli kiteljesedésének folyamatát az ipari forradalom korától napjainkig, valamint azokat az okokat, amelyek az egyes fázisokban kiemelten fontos szerepet játszottak.

A tömeges elterjedés első fázisa - közlekedési oldalról nézve az ipari forradalomtól az első világháborúig elsősorban a vasúti közlekedéssel, a következő, a két világháború közötti a személygépkocsik fokozatos elterjedésével, míg a XX. század ötvenes éveitöl napjainkig tartó harmadik fázis a személyi és a légi közlekedés tömeges elterjedésével van szoros korrelációban.

\begin{abstract}
The aim of this study is to illustrate the process of the second home (leisure dwelling) phenomenon becoming mass-scale, spatially complete, from the age of the Industrial Revolution to the present day, and the reasons that played a key role in each phase.
\end{abstract}

The first phase of mass propagation - from the transport side from the Industrial Revolution to the First World War was mainly due to rail transport, followed by the gradual expansion of passenger cars between the two world wars, the third phase from the fifties to the present has been closely correlated with the mass spread of personal transport and aviation.

\footnotetext{
* Kapcsolattartó szerző. Tel.: +36-76-516-311

E-mail cím: csordas.laszlo@gtk.uni-neumann.hu,csordasl@gmail.com
} 


\section{Bevezetés}

Az ipari társadalom kialakulásával bilokális, azaz két helyhez kötött térhasználat jött létre: a legfontosabb társadalmi alapfunkciók két helyre, a munkahelyre és a lakásra oszlottak. AXX. század utolsó harmadának gazdasági, társadalmi fejlödése azonban ennek a két helyhez kötött életstílusnak a fellazulásához, részbeni felbomlásához, települési-térbeli rendszerének átalakulásához vezetett. A modern ipari-technikai-információs társadalom ugyanis olyan struktúraváltást él át, amilyen az ipari forradalom óta nem volt [3]. A XX. század utolsó harmadában bekövetkezett gazdasági, társadalmi, technológiai fejlődés jelentős változásokat eredményezett a modern társadalmak életében, melyek érintették az élet szinte minden területét. $E$ struktúraváltás egyik sajátos, az urbanizációval összefüggő jegye, hogy a társadalmi alapfunkciók korábbi kettős tagolódásukat elveszítve időben és térben tovább tagolódtak. A lakó- és munkahelyek mellett egyre nagyobb jelentőségre tettek szert a szabadidő eltöltésének színterei. Ennek legfontosabb települési jegyei az üdülö-pihenő térségek megjelenése, elterjedése, térbeli bővülése, valamint a második lakások, ezen belül is az egyre növekvő szabadidőben használt szabadidő-lakások számának ugrásszerü és tömegméretű emelkedése.

A turizmusstatisztikák előszeretettel egyszerüsítik le a turisztikai forgalmat a szálláshelyek (vendégéjszakák) és a vendéglátóhelyek forgalmára, és sokan nem számolnak az utazási költségekkel, holott egyes számítások szerint a teljes forgalomnak több mint $20 \%$-át ezek teszik ki. Az üdülöterületek megközelítése - azaz a közlekedéshordozó infrastruktúrák megléte -, valamint az oda való eljutás formája, milyensége, gyorsasága - azaz a különféle közlekedési eszközök általános elterjedtsége, igénybe vehetősége - alapvető szerepet játszott a turizmus tömegszerü fejlődésének egyes fázisaiban.

E rövid tanulmány célja, hogy bemutassa a jelenség tömegméretűvé válásának, térbeli kiteljesedésének folyamatát az ipari forradalom korától napjainkig, valamint azokat az okokat, amelyek az egyes fázisokban kiemelten fontos szerepet játszottak.

\section{Módszer}

A kutatás során a hazai és a nemzetközi szakirodalom tanulmányozását végeztem el, különös tekintettel az angolszász és a német szakirodalomra. Az első kutatók már a II. világháború előtt is foglalkoztak ezekkel a témákkal, viszont az igazán jelentős kiteljesedés - az 1960-as és 1970-es években - a második otthonok, ezen belül a szabadidőben használt szabadidő-lakások tömeges elterjedésének harmadik szakaszához köthető. Ettől az időszaktól vált az üdülők megjelenése tervezési problémává, mivel a mindennapi élet egyre több területén és egyre többen találkozhattak vele, azaz gazdasági, társadalmi, környezeti, közlekedési stb. hatásait a társadalom szinte valamennyi rétege valamilyen módon megérezte.

\section{Eredmények}

\section{1. A második otthonok és a szabadidő-lakások fogalma, kialakulása az ókortól a tömeges elterjedés koráig}

Értelmezésem szerint a második lakás egy magántulajdonban, vagy tartós használatban lévő ingatlan, amely olyan személy (család) alkalmankénti szállásául szolgál, aki azt nem tekinti állandó lakásának ([5], [6], [7]). Szabadidő-lakásnak a második otthonok közül azok tekinthetök, amelyeket túlnyomóan szabadidőben és csak átmenetileg (hétköznapokon a munkaidő után, hétvégéken vagy a szabadság ideje alatt) elsősorban szabadidős célokra használnak ([Hiba! A hivatkozási forrás nem található.4], [Hiba! A hivatkozási forrás nem található.], [Hiba! A hivatkozási forrás nem található.2], [5], [7]).

Bár a második otthonok iránt megnyilvánuló széleskörü érdeklődés viszonylag új keletű, létezésük mégis nagy múltra tekint vissza, hiszen jellemezte az ókori Egyiptomot, Rómát és Kínát is. A városi lakosság bizonyos időszakban történő vidékre költözése a társadalom felső, jómódú rétegére régóta jellemző volt, akik szolgáikkal együtt néhány szállítható tárggyal megpakolva egyik 
helyröl a másikra költöztek. A jómódú rómaiak akár 15 villával is rendelkezhettek, melyek közül mindig az évszaknak megfelelő legkellemesebbet választották lakóhelyül. A modern kor üdülőihez hasonlóan, de az európai iparosodást megelőző időszakkal ellentétben - amikor a csodálatos vidéki házhoz, illetve a kastélyhoz rendszerint vidéki birtok is tartozott - sok ilyen villát láthattak az akkori kor emberei a tengerparton, vagy másmilyen vízpart közelében. A Como-tavat villák vették körül, a Tiberis partjait több villa szegélyezte, mint bármely más folyót a világon. Seneca szerint nem volt olyan tó, olyan patak, melyet a római gazdagok messzire látszó házainak sora ne szegélyezett volna [3]. A parti üdülöhelyek még népszerübbek voltak. Itália keleti partján a Spezia-öböltől a Salernoöblön túli területekig üdülők helyezkedtek el, legnagyobb koncentrációban a Nápolyi-öbölben. A Mediterráneumban a villagiatura (nyári lak) és a mezandria termelö birtokot is jelentett. A tulajdonosnak több földdarabja volt különbözö helyeken - akár különböző országrészekben -, amelyeket különböző időszakokban - amikor a munka megkívánta - felkeresett. A középkorban ez kifejezett előny volt az elsősorban a városokban pusztító járványok idején, hiszen tulajdonosának nemegyszer a túlélést jelentette egy-egy ilyen távolfekvő vidéki birtok.

Az Európán kívüli "világban" sem volt ismeretlen a második otthon. Ezeket részben ott is a helybeli gazdagok hozták létre, részben az európai, később ázsiai és amerikai gyarmatosítók. Indiában és Kínában korábban is voltak második otthonok (Simla, Darjeeling), míg Latin-Amerikában a XVI-XIX. századi gyarmatosítás után a kalandra vágyó gazdag európaiak alakították ki állandó és második lakásukat. A ma már milliós metropolisok környékén mindenütt megtalálhatók ezek: Petropolis (Rió de Janeiro), Vina del Mar (Valparaiso), Colonia Tovar (Caracas), illetve Varadero (Kuba), Jaracaboa (Dominika) stb. [3]. Ezek a városok napjainkban is fürdővárosok, vagy üdülési központok.

A modern változat közvetlen elődei a Viktória-korabeli brit vadászlakok, illetve ÉszakAmerikában az Atlanti-óceán partján fekvő nyaralók voltak. (Mindkettő rokon vonást mutat az ókori római parti villákkal). A vadászlakhoz (shooting box) elsősorban a vad becserkészése, a telepített nyírfajdok vadászata kötődött. Valójában a társadalom gazdagabb rétegei - ugyanúgy mint római elödeik - több házzal rendelkeztek, melyek közül mindegyiknek megvolt a maga funkciója.

A XIX. század végére a világi és az egyházi arisztokrácia felső, gazdag rétegei elsősorban a XVII. század óta formálódó, kellemes környezetben fekvő uralkodói nyári rezidenciák környékén alakították ki második lakásukat: pl. Versailles és Fontainebleau (Franciaország), Windsor (Anglia), Potsdam (Poroszország), Carszkie Szolo (Oroszország), Schönbrunn (Osztrák-Magyar-Monarchia). $\mathrm{Az}$ angol királyi ház a Buckingham Palotával, a Windsori kastéllyal, Sandringham és Balmoral kastélyával talán a legjobb brit példa, mely jól illusztrálja a XIX. századi ízlést és érdeklődést. Látható tehát, hogy elsősorban a nagyobb fővárosok környékén jelentek meg ezek a második otthonok [5].

\subsection{A második otthonok tömeges elterjedésének fázisai, annak okai, helyszínei}

\subsubsection{Az első fázis: az első világháborúig tartó szakasz}

Az ipari forradalom, az urbanizáció már a XIX-XX. század fordulóján lökést adott a második otthonok első újkori tömegméretű elterjedéséhez, melynek Európában és Észak-Amerikában a következő okai voltak:

- a vasúthálózat fejlödése;

- a mezőgazdasági technika változása, a mezőgazdaságilag müvelt területek növekedése;

- az elvándorlás következtében üresen maradt lakóházak, a falusi népesség számának csökkenése;

- a városi lakosság egy részének gazdagodása;

- a városi lakókörnyezet rosszabbodó állapota (rossz közegészségügyi helyzet, sürü beépítés, kevés zöldterület);

- a megnövekedett szabadidő, a fizetett szabadság bevezetése, a munkaidő csökkenése stb. 
Mindezek hatására minden nagyobb európai város körül - mindenekelőtt Párizs, Berlin, Bécs, Moszkva, Szentpétervár, Prága, Varsó közelében - elsősorban nyáron használt üdülöterületek alakultak ki. Az akkori második lakások olyan területeken fejlődtek, ahol optimális feltételek voltak az üdülésre: erdők közelében, vizek mellett és mindenekelőtt a vasútvonalak mentén. Megállapítható, hogy az európai nagyvárosi agglomerációk körül ekkoriban kialakult üdülötelepek elhelyezkedése radiális, vagy radiál-koncentrikus. Párizs körül (Juvisy, Chaillot, Argenteuil) már 1850 óta fejlődtek ezek az üdülöterületek [8]. Ehhez az időszakhoz köthető a Schrebergartenek elterjedése is. A kiskertek keletkezése a nyugat-európai országokban a 19. század elejéig nyúlik vissza. Eleinte a szegény családokat úgy segítették, hogy számukra földet adtak bérbe. Így alakították ki pl. Kielben 1830 körül, Lipcsében 1832-ben, Berlinben 1833-ban az ún. "szegénykerteket", az angol modell alapján. 1850-töl 1900-ig a kiskertmozgalom tovább bövült, ami "Schreber-egyesületek" alapításához vezetett. Kezdeményezőjük a lipcsei ortopéd orvos, Dr. Schreber volt, aki nyilvános gyermekjátszóterek létesítését kezdte el. Ezeken - pedagógiai okokból kiindulva - ágyakat is el kellett helyezni. Ezekből később családi kertek fejlődtek ki [Hiba! A hivatkozási forrás nem található.0]. A hirtelen gyorsuló, fokozódó iparosítás és a nagyvárosokba való vándorlás következményeként nagy területeket vásároltak fel a tőkések, amelyeket kis parcellákra osztottak, s a munkáscsaládoknak igen drágán bérbe is adták. Ezek az emberek viszont - létező lakásszükségletük kielégítésére - megpróbáltak ott egyszerü hajlékokat építeni.

Más jellegű üdülőházak alakultak ki a klimatikus gyógyhelyeken és gyógyfürdőkben, amelyek eleinte kifejezetten gyógyulási, majd később üdülési célt is szolgáltak. Ezek közé tartozott Karlsbad (ma Karlowy Vary), Marienbad (ma Marienské Lázné), Baden; Monte Carlo, Nizza, Cannes, SaintTropez, Rapallo, Baden-Baden, Oostende, Blackpool-Brighton, Scheweningen stb.

Ugyanezen időszakban jöttek létre az amerikai milliomosok rezidenciái New York-New Port, Rhode Island és az Atlanti-óceán más részein, illetve a kanadai Torontó mellettiek, amelyeket "gentlemen's country houses"-nak neveznek. A kanadai tópartokon fekvő, nagy tradíciójú és igen népszerű halászépületek ("fishing boxes") ugyanebben az időben épültek [Hiba! A hivatkozási forrás nem található.5].

\subsubsection{A második fázis: a két világháború közötti szakasz}

Az első világháború jelentősen lefékezte a második otthonok korábban megindult növekedését a legtöbb európai nagyvárosban. A kiskertek jelentősége viszont növekedett, egyre fontosabb szerepet játszottak a nagyvárosi népesség élelmiszerrel való ellátásában. A kiskertek törvényi szabályozására Bécsben 1920-tól sor került. "Fedélszövetségeket" hoztak létre, amelyekbe a legtöbb kiskerttulajdonost beszervezték/beléptették.

Az 1920-as években a második lakások újkori kialakulásának második szakasza kezdődött el. A szabadidő-lakások fejlődésében - a korábbi időszaktól eltérően - a következő okok játszottak szerepet:

- a személyi közlekedés fejlődése (a robbanómotorok elterjedése különösen a tengerentúlon);

- az olcsóbbá váló és könnyebben megszerezhető szabadidő-lakások;

- pszichológiai okok, azaz a második lakás nagy lehetőséget adott az ember önmegvalósítási igényének kiteljesedéséhez;

- a vidéki tájak, a falusi élet iránti nosztalgia, különösen azoknál, akik korábban a faluból a városba költöztek és származásuk révén kapcsolataik még jelentősek voltak a faluval.

A második szakasz tehát 1918-39 közé tehető, amikor a gazdasági világválság ellenére a második lakások száma jelentősen növekedett. A két világháború közötti időben a személyi közlekedés, a motorizáció megjelenése, a középosztálybeliek számának és anyagi erőforrásainak gyarapodása következtében a második lakások egyre nagyobb számban és az állandó lakóhelytöl egyre távolabb is megjelentek. Általánossá váltak a kisebb-nagyobb villák a városok nyugati, jobb levegőjü részén, valamint tovább fejlődtek a korábbi üdülöhelyek, illetve újak alakultak ki.

Ebben az időszakban Franciaországban 300 ezer [4], Csehszlovákiában 22.964 második lakás [9], Kanadában 61 ezer nyári ház volt [Hiba! A hivatkozási forrás nem található.5]. Németországban, Ausztriában, Skandinávia és Észak-Amerika egyes területein is növekedett a számuk. Igen sok tulajdonos került ki az ún. középrétegek közül. Az üdülésben egyre nagyobb 
szerepet játszottak a második otthonok, amihez hozzájárult bizonyos irodalmi hősök utánzása, a vadnyugati életforma, valamint a szabad természet utáni vágyakozás is. Észak-Amerikában a korábban - elsősorban fából - épült városközpontok tönkremenetele (a gyakori tűzesetek miatt), a lakosság magasabb mobilitási készsége és kényszere, valamint a közlekedéshordozó infrastuktúrák kiépülése (New Deal) következtében kialakultak a városok környéki szuburbiák. Az új otthon megszerzése az esetek jelentős részében a korábbi lakás feladásával is együttjárt, amely többek között magyarázatot ad arra is, hogy az amerikai háztartásoknak miért csak az 5-8\%-a rendelkezik második otthonnal.

\subsubsection{A harmadik fázis: a XX. század közepe óta tartó szakasz}

A második világháború alatt a korábbi üdülötelepek és villák egy része tönkrement, Franciaországban például 20 \%-kal csökkent a számuk. A háború után sok, korábban második lakásként használt épületet azért vették el egykori tulajdonosától, hogy másoknak elsődleges lakóhelyet tudjanak biztosítani. Ez Franciaország atlanti-óceáni partvidéki területein éppúgy megfigyelhető volt, mint pl. Moszkva környékén ([2], [Hiba! A hivatkozási forrás nem található.3]). A szocialista társadalmi berendezkedést "kialakító" országokban ez gyakran kiegészült a korábbi föúri villák elvételével, s vállalati vagy szakszervezeti üdülővé való átalakításával. A II. világháború alatti ínség és a világháború következményei a kiskertek számának további növekedését eredményezték. Sokan a csak nyári időszakban lakott "lugasokat" állandóan lakott házakká alakították át. Így a kiskertkolóniákból néha valóságos települések lettek anélkül, hogy ezek - a teleknagyság, az épületnagyság, az "álutcák" stb. miatt - teljes értékü lakóterületekké váltak volna.

Csak az 1950-es évektől indult el a következő, harmadik fejlődési fázis. Ennek elsődleges oka a motorizáció, a személyi közlekedés általánossá válása ([Hiba! A hivatkozási forrás nem található.4], [Hiba! A hivatkozási forrás nem található.1]), amelynek következtében a távolságok nagymértékben lecsökkentek.

Emellett a

- a jólét (magasabb jövedelmek, a személygépkocsik robbanásserű elterjedése, a háztartásvezetés racionalizálása, technikai feltételeinek javulása);

- a munkaidő csökkenése, az ötnapos munkahét bevezetése;

- a tömbben rendelkezésre álló szabadidő növekedése;

- a fizetett szabadság rendszerének általánossá válása, időtartamának növekedése;

- az urbanizáció társadalmi, foglalkozási, lakókörnyezeti, pszichés hatásai (a civilizációs hatások, a stressz, amelyek elsősorban az ipari és a posztindusztriális társadalmakra jellemzőek);

- a közlekedési infrastruktúra további kiépülése;

- a légi közlekedés elterjedése;

- a gyakori infláció, amely igen sok országban arra kényszerítette az embereket, hogy megtakarított pénzüket a szabadidő eltöltését kellemessé tevő ingatlanok vásárlására fordítsák;

- az ökológiai ismeretek terjedése (környezettudat), valamint az emberek azon törekvése, hogy a természetben - a szabad környezetben és ne a városban - pihenjék ki fáradalmaikat;

- a nosztalgia;

- valamint a tőkebefektetés, a spekuláció stb. játszotta a legfőbb szerepet.

A Schreber-kertek mint a "legrégibb városi második lakás formák" Nyugat-Európában napjainkban egyre inkább átalakulnak pihenő-, virágos-, dísznövénykertekké. A volt szocialista országokban egészen az 1980-as évek végéig nagy jelentősége volt ezeknek a kiskerteknek (Kleingarten, Schrebergarten, ogródki dzialkowe, zahradni, zártkert), hiszen hozzájárultak a népesség élelmiszerrel való ellátásához, emellett bizonyos társadalmi csoportok üdülési igényeit is kielégítették.

Az 1950-es évek óta tartó gazdasági-társadalmi, infrastrukturális fejlődés a második otthonok tömeges elterjedéséhez, "robbanásához" vezetett. A második lakások fejlődésének ebben a 
harmadik szakaszában a tömegjelenséggé váláson kívül az a meghatározó, hogy ezek a lakóhelytöl hatalmas távolságokra, akár más kontinensen is kialakulhatnak, amely összefügg a légi közlekedés elterjedésével is. A fentiek következtében 1960-90 között ugrásszerüen megnőtt a második otthonok száma Nagy-Britanniában, Spanyolországban, Olaszországban, a volt szocialista államok közül a Szovjetunióban, Jugoszláviában, az NDK-ban, Magyarországon és Lengyelországban [5]. Tovább emelkedett a szabadidő-lakások száma azokban az országokban is, amelyek már korábban is sok üdülővel rendelkeztek, mivel új nyaralótelepeket létesítettek: így Franciaországban, a skandináv államokban, az NSzK-ban, Ausztriában, Csehszlovákiában, az USA-ban és Kanadában. Európán és Észak-Amerikán kívül elterjedtek Ausztráliában és Új-Zélandon, valamint Latin-Amerikában (elsősorban Argentínában, Brazíliában, Mexikóban és a Karib-tenger több államában) többek között azért, mert a klíma miatt szinte egész évben használhatók az ottani üdülőépületek.

\section{Következtetések - a szabadidő-lakások elterjedésének következményei}

A második otthonok - a politikai és gazdasági rendszertöl függetlenül - minden modern államban megtalálhatók. A második otthonok esetében egy társadalmi, területi diffúziós folyamatról van szó, amely mindenekelőtt a nagyvárosokból indul ki, de hatásai a városkörnyéket, a közeli és távoli idegenforgalmi területeket is érintik. A szabadidő-lakás egészen általánosan lényegi jele a társadalom növekvő urbanizációs szintjének. A második lakások területi elterjedése tehát része a városfejlődési folyamatnak és a szuburbanizációnak is: a szezonális, vagy egyesek által rekreációs szuburbanizációnak nevezett jelenség egyedi esetekben "valódi" szuburbanizációhoz vezethet, azaz a második lakások állandó lakássá alakulnak.

Ennek jelei Magyarországon is megfigyelhetők, hiszen már a 2001. évi népszámláláskor a 252 ezerböl több mint 6 ezret lakott üdülöként tartottak nyilván. A 2001. évi népszámlálást megelőző üdülö-összeírási adatok szerint legalább 80 olyan település volt - elsősorban a nagyobb tavak (Balaton, Velencei-tó), gyógy- és termálfürdök stb. közelében -, ahol a nyaralóépületek száma meghaladta a lakásokét, azaz üdülö-településnek nevezhetők.

\section{Köszönetnyilvánítás}

Köszönettel tartozunk a kutatás támogatásáért, amely az EFOP-3.6.1-16-2016-00006 „A kutatási potenciál fejlesztése és bővítése a Neumann János Egyetemen" pályázat keretében valósult meg. A projekt a Magyar Állam és az Európai Unió támogatásával, az Európai Szociális Alap társfinanszírozásával, a Széchenyi 2020 program keretében valósul meg.

\section{Irodalomjegyzék}

[1] Baumhackl, H. (1988): The Phenomenon of Second Homes within the Framework of the Housing Markets: the Vienna Example. In: Lichtenberger, E. - Pécsi, M. (Eds.): Contemporary Essays in Austrian and Hungarian Geography. (Studies in Geography in Hungary 22.) Akadémiai Kiadó, Budapest. pp. 225-240.

[2] Brier, M. A. - Brier, M. (1971): Les résidences secondaires. Population, 26. pp. 11-89.

[3] Coppock, J. T. (Ed.) (1977): Second Homes: Curse or Blessing. Pergamon, Oxford. Geogr. Series

[4] Cribier, F. (1968): 300.000 résidences secondaires. Paris

[5] Csordás, L. (1995): Szabadidö-lakások az Alföldön. Kandidátusi értekezés, p. 154 + p. 260 melléklet + 275 térkép

[6] Csordás, L. (1999): Second homes in Hungary. In: Duró A. (Ed.) Spatial Research in Support of the European Integration, MTA RKK, Pécs, (Discussion Papers, Special) pp. 145-160.

[7] Csordás L. (2007): A második otthonok definíciója és a jelenség térbeli hatásai. In: Kovács Cs. - Pál V. (szerk.): $A$ társadalmi földrajz világai. SZTE Gazdaság- és Társadalomföldrajzi Tanszék, Szeged, pp. 117-131.

[8] Freitag, R. D. von (1970): Naherholungsraum und Naherholungsverkehr: Beispiel Paris In: Ruppert, K.-Maier, J. (Eds.): Zur Geographie der Freizeitverhaltens. Beiträge zur Fremdenverkehrsgeographie. (Münchner Studien zur Sozial- und Wirtschaftsgeographie 6.) pp. 79-88.

[9] Gardavsky, V. (1975): Geografie individuálni vikendové rekreacne v CSR. In: Acta Universitatis Carolinae, Geographica. 1-2. pp. 125-128.

[10] Hansely, H. J. (1987): Kleingartenbesitz und Kleingartenwunsch. Statistische Mitteilungen der Stadt Wien, 1. pp. 18-25. 
[11] Kowalczyk, A. (1994): Geograficzno-spoleczne problemy zjawiska "drugich domów". p. 178

[12] Martonné Erdős K. (1990): Az egyéni rekreáció lehetőségei és megvalósulásai Miskolc környékén. Kandidátusi értekezés, kézirat. KLTE Debrecen. p. 158

[13] Preobrazsenszkij, V. S. - Vedenin, Ju. A. - Zorin, L. V. - Muhina, L. I. (1974): Territorialnaja rekreacionnaja szisztema, kak objekt izucsenija geograficseszkih nauk. Izvesztija A. N. SzSzSzR. Szerija Geografija. 2. pp. 34-42.

[14] Ruppert, K. (1973): Der Zweitwohnsitz - geographisches Faktum und landesplanerisches Problem. In: Geographische Aspekte der Freizeitwohnsitze. In: WGI-Berichte z. Regionalforschung. 11. pp. 1-54.

[15] Wolfe, R. I. (1977): Summer Cottages in Ontario: Purpose-built for an Inessential Purpose. In: Coppock, J. T. (Ed.): Second Homes: Curse or Blessing. Pergamon, Oxford. Geogr. Series. pp. 17-34. 